\section{An Improved Method for Cloning PCR Fragments}

\author{
David B. Mitchell, ${ }^{1}$ \\ Nicolas Ruggli, and \\ Jon-Duri Tratschin
}

Institut für Viruskrankheiten und Immunprophylaxe, Hagenaustrasse 74, 4025 Basel, Switzerland

'Present address: F. Hoffmann-LaRoche AG, CH-4002, Basel, Switzerland.
Although the polymerase chain reaction $(\mathrm{PCR})^{(1)}$ provides a powerful method for amplifying DNA from extremely small amounts of starting material, blunt-end cloning of DNA fragments generated by PCR has proved to be difficult, even after repairing the ends with $T_{4}$ DNA polymerase or Klenow fragment. A reasonable level of success has been achieved by incorporating restriction endonuclease sites at the ends of the primers; however, this approach is only useful when the sequence of the fragment is known. The observation that DNA polymerases can add a single nontemplated residue (with a distinct preference for adenosine) to dsDNA ${ }^{(2)}$ have led to a number of general cloning methods ${ }^{(3-6)}$ taking advantage of the single $3^{\prime}$ A overhang. All of these methods rely on vectors having single $T$ overhangs generated either by enzymatic tailing of the linearized vector ${ }^{(3,5)}$ or by cleavage with the restriction enzymes $\mathrm{HphI}^{(6)}$ or $\mathrm{XcmI} .^{(4)}$

Analysis of all 11 restriction enzymes generating a single-base overhang showed that in all cases the efficiency of ligation and subsequent recutting was less than $95 \%$. This is compared to the 32 enzymes with either two or three base overhangs where, in all except three cases, the efficiency of ligation and subsequent recutting was greater than $95 \%$ (New England Biolabs Catalogue, 19901991). It may well be that there is a connection between the ability of DNA polymerases to add a single nontemplated base and the poor performance of ligase to join these overhangs. Ligase could recognize a single-base overhang as an error as it "knows" that single bases are nontemplated additions by DNA polymerases. There is suggestive evidence for this in that DNA cut with the restriction enzymes BstNI (CC'WGG), PleI (GAGTCNNNN'N), ScrFI (CC'NGG), and Tth111I (GACN'NNGTC), which all generate single-base overhangs cannot be religated following cleavage (New England Biolabs Catalogue, 1990-1991).

Bearing this in mind, we decided to design a cloning procedure that would take into account the A overhangs generated in the PCR and also minimize the problems associated with ligating single base overhangs. We have done this by electing to use a tailing procedure to obtain PCR fragments having extended single-stranded overhangs of two to three adenosine residues. Thus, we have designed a compact cassette containing two copies of the recognition sequences for $X \mathrm{cmI}$ and $P f \mathrm{MI}$ and a single recognition sequence for $B c g I$. Cleavage with these enzymes generates either one, two, or three $\mathrm{T}$ overhangs following the removal of an internal fragment (Fig. 1). In addition, we have flanked these restriction sites (which generate the $\mathrm{T}$ overhangs) with MscI sites to enable the complete cassette to be removed by bluntend digestion. The internal fragment also contains a SmaI site that can be used to reduce background due to uncut vector if necessary.

The cassette was constructed by synthesizing an oligonucleotide that contained the coding sequence for the cassette as well as flanking regions containing restriction sites PstI and $B a m$ HI. The oligo was made doublestranded, cleaved with PstI and BamHI, and ligated into pBluescript II SK+ (Stratagene, La Jolla, CA). The insert is 48 nucleotides long, maintaining the reading frame of the $\beta$-galactosidase gene allowing blue/white selection of recombinants. A naturally occurring $B c g I$ site in the ampicillin gene of the pBluescript vector was removed using site-directed mutagenesis with the oligonucleotide (5'-GTGTATGCGCCTACCGAGTTG-3') while maintaining the amino acid sequence of the ampicillin resistance gene. Vectors were prepared by digestion of the plasmid DNA with the appropriate restriction enzyme and elution from low-melting-point agarose.

A 764-bp fragment prepared by PCR was eluted from a $1.5 \%$ low-meltingpoint agarose gel. The fragment was polyadenylated in a $50-\mu]$ reaction $[100$ mM K cacodylate $\mathrm{pH} 6.6,12.5 \mathrm{~mm}$ Tris/ $\mathrm{HCl}, \mathrm{pH} 7.0,125 \mu \mathrm{g} / \mathrm{ml}$ BSA, $0.1 \mathrm{~mm}$ DTT, $1 \mathrm{~mm} \mathrm{CoCl}, 20 \mu \mathrm{M}$ dATP, 10 units of terminal deoxytransferase (Boehringer Mannheim), 0.5-1 pmole of 3'-OH termini] for between 3 and $16 \mathrm{~min}$ at $37^{\circ} \mathrm{C}$. The reaction was terminated by the addition of $0.5 \mathrm{~m}$ EDTA pH $8.0(2 \mu \mathrm{l})$ and then extracted twice with an equal volume of phenol/chloroform and once with an equal volume of chloroform prior to ethanol precipitation. Polyadenylated fragments were ligated into prepared vector in $10-\mu \mathrm{l}$ reactions $(50 \mathrm{~mm}$ Tris/ $\mathrm{HCl}, \mathrm{pH} 7.8,10 \mathrm{~mm} \mathrm{MgCl}_{2}, 1 \mathrm{~mm}$ DTT, $1 \mathrm{~mm}$ ATP, $100 \mu \mathrm{g} / \mathrm{ml} \mathrm{BSA}, 20 \mathrm{ng}$ of vector, and 0.8 Weiss units of $T_{4}$ DNA ligase) and incubated overnight at $16^{\circ} \mathrm{C}$. The ligation mix was transformed into $E$. coli XL-1 Blue competent cells and plated 


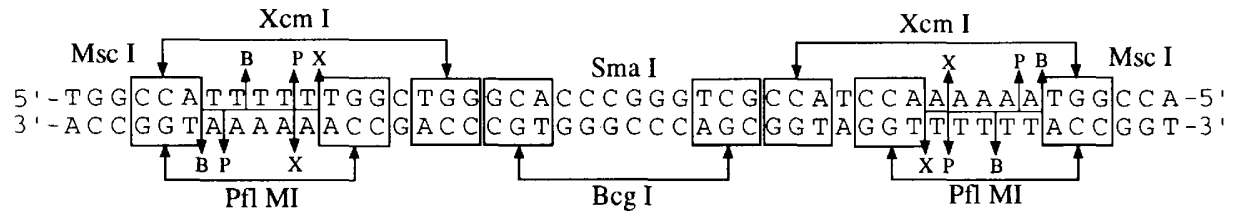

FIGURE 1 The cassette showing the restriction recognition sites and the sites of cleavage. The orientation of the cassette in pBluescript II SK+ is from PstI to BamHI (left to right).

on LB-agar plates containing ampicillin $(50 \mu \mathrm{g} / \mathrm{ml})$, IPTG $(0.1 \mathrm{~mm})$, and X-gal (40 $\mu \mathrm{g} / \mathrm{ml})$. White colonies were selected and screened directly by PCR. ${ }^{(7)}$

Two vector/insert ratios (1:1 and 1:4) and a number of different polyadenylation times for all three vectors were tried. In our hands, only vector cut with PflM1 gave positive clones. There were a few white colonies with $B c g I-$ and XcmI-cut vector; however, these proved to contain no insert. Sequence analysis of some of these clones showed that either the vector was uncut or that a deletion of part of the polylinker including the cassette had occurred. We also attempted to ligate untreated PCR fragment into the XcmIcut vector but with no success.

In the case of the PflM1-cut vector, there was no discernible difference between the two vector/insert ratios. The percentage of white colonies containing inserts varied nonlinearly from $33 \%$ to $90 \%$, depending upon the time incubated with terminal deoxytransferase. All time points sampled between 3 and 16 min produced positive clones, but we have found that polyadenylation for 3-5 min produced a high percentage of recombinants. To check the vector/insert junctions, four clones from different time points were sequenced and all found to have the expected junction. Although we cannot rule out the possibility that inserts with more than three A's could be ligated into the vector, we have so far failed to observe such an event. We also sequenced a number of white clones without inserts and found as with similar clones from $X \mathrm{cmI}$ - and $B c g I-c u t$ vectors there was neither a deletion removing the entire cassette and some flanking polylinker or the vector was intact (uncut).

We are unable to explain the lack of positive clones with $B c g I$-cut vector, but the lack of positives with the $X \mathrm{cmI}$-cut vector is not surprising given the general difficulty found in ligating single-base overhangs. We observed an overall reduction in the number of transformants with both $X c m I-$ and $B c g I-c u t$ vectors that may, in part, account for the lack of positive colonies. A number of "white" colonies in all cases proved to be native vector. It may be that the addition of the cassette to the already lengthy pBluescript II polylinker has in some cases affected the $\beta$-galactosidase $\alpha$-peptide leading to decreased production of $\beta$-galactosidase. We believe that the method presented here should enable the cloning of any PCR fragment without resorting to expensive kits or supercompetent cells.

\section{ACKNOWLEDGMENTS}

D.B.M. was supported by the Swiss National Science Foundation (Grant No. 31-25695.88) and N.R. by the Swiss Federal Veterinary Office.

\section{REFERENCES}

1. Saiki, R.K., S. Scharf, F. Faloona, K.B. Mullis, G.T. Horn, H.A. Erlich, and N. Arnheim. 1985. Enzymatic amplification of $\beta$-globin sequences and restriction site analysis for diagnosis of sickle cell anemia. Science 230: 1350-1354.

2. Clark, J.M. 1988. Novel non-templated nucleotide addition reactions catalyzed by procaryotic and eucaryotic DNA polymerases. Nucleic Acids Res. 16: 9677-9686.

3. Holton, T.A. and M.W. Graham. 1991. A simple and efficient method for direct cloning of PCR products using ddT-tailed vectors. Nucleic Acids Res. 19: 1156.

4. Kovalic, D., J.-H. Kwak, and B. Weisblum. 1991. General method for direct cloning of DNA fragments generated by the polymerase chain reaction. Nucleic Acids Res. 19: 4560 .

5. Marchuk, D., M. Drumm, A. Saulino, and F.S. Collins. 1991. Construction of T-vectors, a rapid and general system for direct cloning of unmodified PCR products. $\mathrm{Nu}$ cleic Acids Res. 19: 1154.

6. Mead D.A., N.P. Pey, C. Herrnstadt, R.A. Marcil, and L.M. Smith. 1991. A universal method for the direct cloning of PCR am- plified nucleic acid. Bio/Technology 9: 657-663.

7. Sandhu, G.S., J.W. Precup, and B.C. Kline. 1989. Rapid one-step characterization of recombinant vectors by direct analysis of transformed Escherichia coli colonies. BioTechniques 7: 689-690.

Received March 16, 1992; accepted in revised form May 27, 1992. 


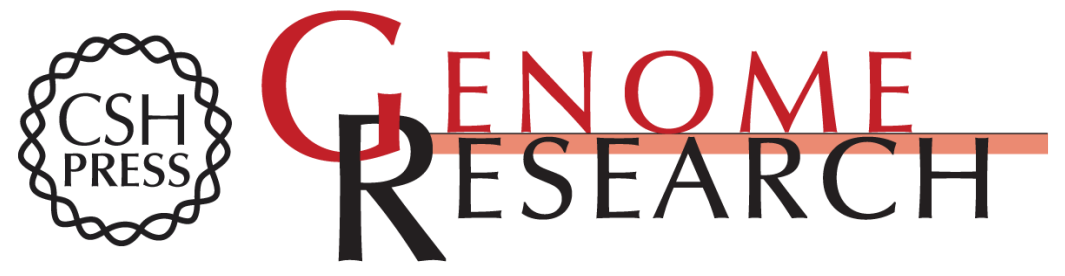

\section{An improved method for cloning PCR fragments.}

D B Mitchell, N Ruggli and J D Tratschin

Genome Res. 1992 2: 81-82

Access the most recent version at doi:10.1101/gr.2.1.81

$\begin{array}{ll}\text { References } & \text { This article cites } 7 \text { articles, } 1 \text { of which can be accessed free at: } \\ \text { http://genome.cshlp.org/content/2/1/81.full.html\#ref-list-1 }\end{array}$

\section{License}

Email Alerting Receive free email alerts when new articles cite this article - sign up in the box at the Service top right corner of the article or click here.

\section{Affordable, Accurate Sequencing.}

To subscribe to Genome Research go to: https://genome.cshlp.org/subscriptions 